\title{
MECHANICAL AND WETTING PROPERTIES OF NANOSILICA/EPOXY-COATED STAINLESS STEEL
}

\section{MEHANSKE IN POVRŠINSKE LASTNOSTI PREMAZA IZ SILICIJEVIH NANODELCEV IN EPOKSIDNE SMOLE NA NERJAVNEM JEKLU}

\author{
Marjetka Conradi $^{1}$, Gaber Intihar', Milena Zorko \\ 1Institute of Metals and Technology, Lepi pot 11, 1000 Ljubljana, Slovenia \\ ${ }^{2}$ National Institute of Chemistry, Hajdrihova 19, 1000 Ljubljana, Slovenia \\ marjetka.conradi@imt.si \\ Prejem rokopisa - received: 2015-03-13; sprejem za objavo - accepted for publication: 2015-04-03
}

doi:10.17222/mit.2015.060

\begin{abstract}
Submicron silica particles surface-capped with diglycidyl ether of bisphenol A were dispersed in a solution of epoxy resin hardener and acetone. The resulting suspension was then spin-coated onto the surface of austenitic stainless steel of type AISI $316 \mathrm{~L}$ and cured at temperature, generating a thick silica/epoxy coating $300 \mathrm{~nm}$. An epoxy coating without nanosilica was also prepared as a reference in the same manner. The coatings were further functionalized with fluoroalkylsilane (FAS17) for an additional improvement of the non-wetting properties. The mechanical properties of epoxy coatings filled with different combinations of silica particles $30 \mathrm{~nm}, 200 \mathrm{~nm}$ and $600 \mathrm{~nm}$ were compared and characterized using scratch-resistance tests. The effects of incorporating the silica particles on the surface characteristics of the epoxy-coated steel were investigated with contact-angle and surface-energy evaluations. The surface morphology of the coatings was characterized with scanning electron microscopy (SEM). The results indicate that the silica particles significantly improved the microstructure of the coating matrix, which was reflected in an increased damage resistance, a reduced degree of delamination and an induced hydrophobicity. We observed the formation of micrometre-size silica agglomerates as a consequence of the epoxy-matrix curing process. We connected the significantly increased hydrophobicity in silica/epoxy coatings $200 \mathrm{~nm}$ and $(30+600) \mathrm{nm}$ to the proper combination of micro- and nano-roughness created by the agglomerates embedded in the epoxy matrix.
\end{abstract}

Keywords: silica, composite coatings, scratch test, hydrophobicity

Submikrometrske silicijeve delce, prevlečene z diglicidil etrom bisfenola A, smo dispergirali v raztopini epoksidne smole, utrjevalca in acetona. Nastalo suspenzijo smo nato z vrtenjem nanesli na površino avstenitnega nerjavnega jekla tipa AISI 316L in jo dokončno zamrežili pri povišani temperaturi. Dobili smo $300 \mathrm{~nm}$ debelo plast prevleke silicij-epoksidna smola. Tako smo za primerjavo lastnosti pripravili tudi prevleko iz čiste epoksidne smole. Vse prevleke smo dodatno funkcionalizirali s fluoroalkilsilanom (FAS17) za povečanje hidrofobnosti površine. Mehanske lastnosti prevlek iz epoksidne smole, obogatene z različnimi kombinacijami silicijevih delcev $30 \mathrm{~nm}, 200 \mathrm{~nm}$ in $600 \mathrm{~nm}$, smo preizkušali z razenjem. Vpliv vključevanja silicijevih delcev $\mathrm{v}$ epoksidno smolo na površinske lastnosti prevlek smo analizirali z meritvami stičnih kotov ter površinske energije. Morfološke lastnosti prevlek smo karakterizirali z vrstično elektronsko mikroskopijo (SEM). Rezultati kažejo, da vključitev silicijevih delcev znatno izboljša mikrostrukturo premaza epoksidne matrike, kar se je pokazalo kot povečana odpornost proti poškodbam, zmanjšanje stopnje delaminacije in inducirane hidrofobnosti. Opazili smo tvorbo silicijevih aglomeratov mikrometrske velikosti kot posledico zamreževanja polimera pri povišani temperaturi. Močno povečano hidrofobnost na površini prevlek silicij-epoksidna smola $200 \mathrm{~nm}$ in $(30+600) \mathrm{nm}$ smo povezali z mikro- in nanohrapavostjo, inducirano s tvorbo aglomeratov v matriki epoksidne smole.

Ključne besede: silika, kompozitne prevleke, preizkus razenja, hidrofobnost

\section{INTRODUCTION}

In recent decades, polymer composites have started to see uses in many applications as adhesives and matrix resins. Epoxy resin is one of the most common polymer matrices that are widely used to protect steel reinforcements in concrete structures ${ }^{1}$. It has excellent mechanical properties, chemical resistance, good electrical insulating properties, and in addition, it also provides an effective physical barrier between the metal and the environment containing an aggressive species, such as an enhanced chloride-ion concentration.

The practical use of epoxy coatings in industry, however, is seriously limited by their poor impact resistance and stress-cracking resistance due to a highly cross- linked structure ${ }^{2}$, as well as by their susceptibility to damage by surface abrasion and wear ${ }^{3}$. To overcome this drawback, researchers have made numerous attempts to improve the properties of epoxy by adding various nanofillers ${ }^{4-8}$. They studied the favourable effects of particle size, volume fraction and the quality of the dispersion on the mechanical response of polymer composites ${ }^{4,9-14}$.

A lot of work has also been done in the field of modifying the surface wettability through the controlled tailoring of the surface morphology and the surface energy ${ }^{15,16}$. In this respect, the surfaces were coated with low-surface-energy compounds ${ }^{17}$ and/or their roughness was increased, i.e., by etching or nanoparticle deposition $^{18,19}$. A further technological step is represented by the synthesis of superhydrophobic coatings inspired by 
nature (i.e., the lotus leaf). Such coatings are a solution for corrosion, biofouling as well as water- and air-drag reduction applications. Additionally, they improve the mechanical characteristics of the surfaces. For example, nanosilica/epoxy coatings are increasingly attractive and have many potential applications in paints, coatings, sealants, adhesives, etc., due to their low cost, good adhesion to most substrates, good corrosion resistance, good scratch resistance, etc. ${ }^{13}$

Here, we investigate the influence of different sizes of silica nanoparticles $(30 \mathrm{~nm}, 200 \mathrm{~nm}$ and $600 \mathrm{~nm})$ on the surface morphology and mechanical characteristics of epoxy coatings on austenitic stainless steel of type AISI 316L. Through the implementation of silica nanoparticles into the epoxy matrix, we focus on a modification of the surface roughness of the epoxy coating that results, in combination with appropriate surface chemistry, in a significantly improved hydrophobicity.

\section{EXPERIMENTAL}

Materials. - Epoxy resin (Epikote 816, Momentive Specialty Chemicals B.V.) was mixed with a hardener Epikure F205 (Momentive Specialty Chemicals B. V.) in the mass ratio $100: 53 \%$ and used as the matrix in the composite. Composite-reinforcing silica $\left(\mathrm{SiO}_{2}\right)$ nanoparticles with mean diameters of $30 \mathrm{~nm}$ were provided by Cab-O-Sil, whereas $200 \mathrm{~nm}$ and $600 \mathrm{~nm}$ particles were synthesized following the Stöber-Fink-Bohn method in our laboratory ${ }^{20}$. Diglycidyl ether of bisphenol A (Sigma-Aldrich) was used as the silica-surface modifier to prevent agglomeration. Imidazole (Sigma-Aldrich) served as a reaction catalyst. Austenitic stainless steel of type AISI 316L was used as a substrate.

Surface modification of silica. - Silica and diglycidyl ether of bisphenol A were mixed in the mass ratio $2: 3$ and dispersed in $50 \mathrm{~mL}$ of toluene in the presence of imidazole $(w=25 \%)$. The mixture was then refluxed at $100{ }^{\circ} \mathrm{C}$ for $2 \mathrm{~h}$. To remove the by-product it was centrifuged three times using acetone as a solvent. The remaining silica was then dispersed in acetone and stirred at room temperature for $2-3 \mathrm{~h}$. Finally, the silica was dried in an oven at $110{ }^{\circ} \mathrm{C}$ for $2 \mathrm{~h}$.

Steel-substrate preparation. - The steel sheet with a thickness of $1.5 \mathrm{~mm}$ was cut into discs with diameters of $25 \mathrm{~mm}$. Prior to the application of the coating, the steel discs were diamond polished following a standard mechanical procedure and then cleaned with ethanol in an ultrasonic bath.

Composite coating preparation. - Epoxy-based composites were prepared by blending with a mass fraction $2 \%$ of $30 \mathrm{~nm} / 200 \mathrm{~nm} / 600 \mathrm{~nm}$ surface-modified $\mathrm{SiO}_{2}$ particles. To improve the dispersion of the silica particles in the coating, they were dispersed in epoxy resin using acetone as a solvent. Prior to the addition of the silica particles, both the resin and the hardener were separately diluted in acetone in a mass ratio of $1: 4$. The nanopar- ticles were then dispersed in the epoxy resin/acetone solution using ultrasonification for $20-30 \mathrm{~min}$ at room temperature. After adding the hardener/acetone solution in the next step, the mixture was manually stirred for a 5 min. Finally, a drop $19 \mathrm{mg}$ of the silica/epoxy resin/hardener/acetone mixture was poured onto the steel substrate disc and a uniform film was then applied to the substrate by a spin-coating process. The composite coatings were then cured in two steps: first pre-cured at $70{ }^{\circ} \mathrm{C}$ for $1 \mathrm{~h}$ and then post-cured at $150{ }^{\circ} \mathrm{C}$ for another hour. The resulting coatings on the steel-substrate plates were thick $300 \mathrm{~nm}$, as determined by ellipsometry. For comparison, neat epoxy coatings without silica fillers were also prepared and cured in the same process as the composites. Finally, to additionally improve the non-wetting properties, the coatings were functionalized by dip-coating in ethanolic fluoroalkylsilane (FAS17, $\mathrm{C}_{16} \mathrm{H}_{19} \mathrm{~F}_{17} \mathrm{O}_{3} \mathrm{Si}$, SigmaAldrich).

Scanning electron microscopy (SEM). - SEM analysis using FE-SEM Zeiss SUPRA 35VP was employed to investigate the morphology of the silica/epoxy coatings' surfaces.

Scratch test. - The scratch test was performed with a Revetest Scratch tester (CSM Instruments). In the experiment, a scratch length of $10 \mathrm{~mm}$ was made using a diamond tip and a linearly increased normal load from $1 \mathrm{~N}$ to $5 \mathrm{~N}$ at a speed of $5 \mathrm{~mm} / \mathrm{s}$. Four tests were performed per sample. A light microscope was employed to analyse the scratches.

Contact-angle and surface-energy measurements. The static contact-angle measurements of water (W) on a clean AISI 316L diamond-polished sample and on the pure epoxy and silica/epoxy composite coatings prepared on an AISI 316L steel substrate were performed using a surface-energy evaluation system (Advex Instruments s. r. o.). Liquid drops of $5 \mu \mathrm{L}$ were deposited on different spots of the substrates to avoid the influence of roughness and gravity on the shape of the drop. The drop contour was analysed from the image of the deposited liquid drop on the surface and the contact angle was determined by using Young-Laplace fitting. To minimize the errors due to roughness and heterogeneity, the average values of the contact angles of the drop were calculated approximately $30 \mathrm{~s}$ after the deposition from at least five measurements on the studied coated steel. All the contact-angle measurements were carried out at $20^{\circ} \mathrm{C}$ and ambient humidity. As the contact angles were only available for water, an equation-of-state approach ${ }^{21,22}$ was used to calculate the corresponding surface energies.

Surface roughness. - A profilometer, model Form Talysurf Series 2 (Taylor-Hobson Ltd.), was employed for the surface analysis. The instrument has a lateral resolution of $1 \mu \mathrm{m}$ and a vertical resolution of about $5 \mathrm{~nm}$. It measures the surface profile in one direction. TalyMap gold 4.1 software was used for the roughness analysis. The software offers the possibility to calculate 
the average surface roughness, $S_{\mathrm{a}}$, for each sample, based on the general surface-roughness equation:

$$
S a=\frac{1}{L_{x}} \frac{1}{L_{y}} \int_{0}^{L_{x}} \int_{0}^{L_{y}}|z(x, y)| \mathrm{d} x \mathrm{~d} y
$$

where $L_{x}$ and $L_{y}$ are the acquisition lengths of the surface in the $x$ and $y$ directions and $z(x, y)$ is the height. To level the profile, corrections were made to exclude the general geometrical shape and possible measurement-induced misfits.

\section{RESULTS AND DISCUSSION}

\subsection{Scratch resistance}

Typical scratches in the $300 \mathrm{~nm}$ thick pure epoxy coating and the $300 \mathrm{~nm}$ thick epoxy coating filled with $200 \mathrm{~nm}$ silica particles are presented in Figure 1. The scratch profile as well as the resistance of the other silica/epoxy coatings is analogous to the $200 \mathrm{~nm}$ silica/ epoxy coating under investigation, and thus not provided here. It is clear that there is much less displaced material in the case of the silica/epoxy coating compared to the pure epoxy coating. It also seems that the pure epoxy coating is much more brittle than the silica/epoxy coating. This, altogether, indicates that the embedded silica particles can improve the scratch resistance and enhance the toughness of the epoxy coating. In addition, the scratch-test results also suggest that the scratch resistance of the coatings is related to the interaction force between the coating and the steel substrate, which is apparently improved for the silica/epoxy coating.

\subsection{Wetting properties}

To analyse the surface wettability, five static contactangle measurements with water (W) were performed on different spots all over the sample and used to determine the average contact-angle values with an estimated error in the reading of $(\theta \pm 1.0)^{\circ}$ and for the calculation of the surface energy. The wettability, however, was not possible to assess using non-polar liquids for the contactangle measurements as they spread out on the coatings $\left(\theta \pm 0^{\circ}\right)$. The contact angles and the surface energies for the epoxy and silica/epoxy coatings on the AISI 316L substrate in comparison to the clean, diamond-polished AISI 316L sample are reported in Table 1.
It was observed that all the investigated silica/epoxy coatings exhibited significantly higher values of static water-contact angles compared to the clean AISI 316L sample, as well as the AISI 316L substrate blended with pure epoxy. This suggests that the microstructure change of the epoxy coating upon adding the silica particles was reflected in an increased surface roughness, which is known to impart a hydrophobic effect to the surface ${ }^{23}$.

The highest values of the static water angles, close to $120^{\circ}$, were however measured in the case of two types of silica/epoxy coatings: $200 \mathrm{~nm}$ silica/epoxy coatings and in case of silica/epoxy coatings filled with a combination of $30 \mathrm{~nm}$ and $600 \mathrm{~nm}$ silica particles. Possible reasons for this observation will be discussed in the following section on surface morphology and surface roughness.

Table 1: Surface properties of diamond-polished AISI 316L substrate and AISI 316L substrate when blended with pure epoxy and various types of silica/epoxy coatings. Static contact angles were measured with water $\left(\theta^{\mathrm{W}}\right)$ and the corresponding surface energies were calculated using an equation-of-state approach.

Tabela 1: Površinske lastnosti z diamantno pasto polirane površine podlage AISI 316L in AISI 316L, prevlečne s čisto epoksidno smolo in različnimi prevlekami iz silicij-epoksidne smole. Statični stični koti so bili izmerjeni $\mathrm{z}$ vodo $\left(\theta^{\mathrm{W}}\right)$, ustrezne površinske energije pa so bile izračunane $\mathrm{z}$ enačbo stanja.

\begin{tabular}{|l|c|c|}
\hline \multicolumn{1}{|c|}{ Substrate } & $\begin{array}{c}\text { Contact angle } \\
\theta^{\mathrm{W} /{ }^{\circ}}\end{array}$ & $\begin{array}{c}\text { Surface energy } \\
\gamma^{\text {tot }} /(\mathrm{mN} / \mathrm{m})\end{array}$ \\
\hline AISI & 68.4 & 42.7 \\
\hline AISI + epoxy & 80.2 & 35.4 \\
\hline AISI + 30 nm silica/epoxy & 110.1 & 17.0 \\
\hline AISI + 200 nm silica/epoxy & 117.7 & 12.8 \\
\hline AISI + 600 nm silica/epoxy & 110.1 & 17.0 \\
\hline $\begin{array}{l}\text { AISI + (30 + 200) nm } \\
\text { silica/epoxy }\end{array}$ & 111.7 & 16.1 \\
\hline $\begin{array}{l}\text { AISI + (200 + 600) } \mathrm{nm} \\
\text { silica/epoxy }\end{array}$ & 111.0 & 16.5 \\
\hline $\begin{array}{l}\text { AISI + (30 + 600) } \mathrm{nm} \\
\text { silica/epoxy }\end{array}$ & 118.4 & 12.5 \\
\hline
\end{tabular}

As the contact angles were only available for water, an equation-of-state approach ${ }^{21,22}$ was used to calculate the surface energies with Equation (1):

$$
\cos \theta=-1+2 \sqrt{\frac{\gamma_{\mathrm{s}}}{\gamma_{1}}} e^{-\beta\left(\gamma_{1}-\gamma_{\mathrm{s}}\right)^{2}}
$$

For a given value of the surface tension of the probe liquid $\gamma_{1}$ (i.e., for water $\gamma_{1}=72.8 \mathrm{mN} / \mathrm{m}^{24}$ ) and $\theta^{\mathrm{w}}$ measured on the same solid surface, the constant $\beta$ and

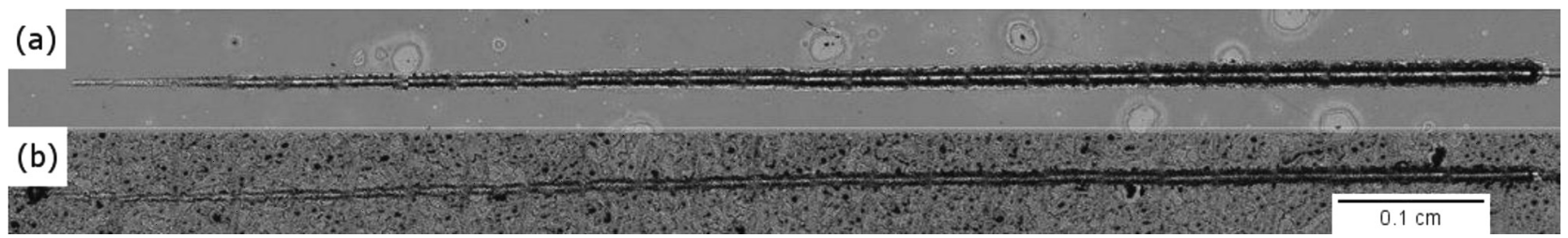

Figure 1: Light micrographs revealing the typical morphology of scratches: a) for the thick pure epoxy coating $300 \mathrm{~nm}$ on AISI $316 \mathrm{~L}$ and b) for the thick epoxy coating $300 \mathrm{~nm}$ filled with silica particles $200 \mathrm{~nm}$ on AISI 316L

Slika 1: Svetlobna mikroskopija prikazuje značilno morfologijo prask: a) na $300 \mathrm{~nm}$ debeli prevleki iz čiste epoksidne smole in b) na 300 nm debeli prevleki iz epoksidne smole, obogatene s silicijevimi delci $200 \mathrm{~nm}$ 

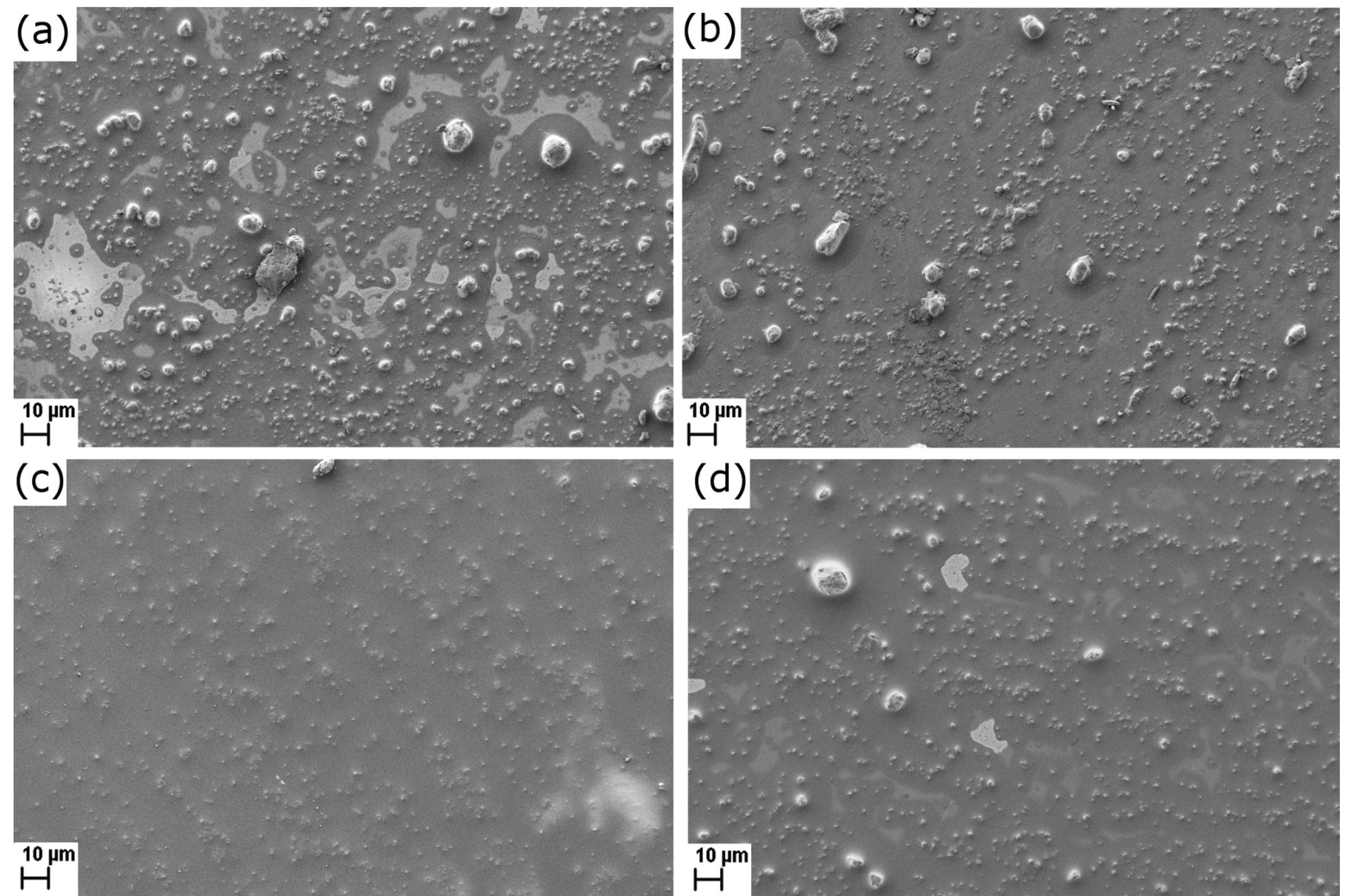

Figure 2: SEM images of AISI 316L substrate when blended with: a) silica/epoxy $30 \mathrm{~nm}$, b) silica/epoxy $200 \mathrm{~nm}$, c) silica/epoxy $600 \mathrm{~nm}$ and d) silica/epoxy coating $(30+600) \mathrm{nm}$

Slika 2: SEM-posnetki podlage AISI 316L, prevlečene s prevlekami iz: a) $30 \mathrm{~nm}$ silicij-epoksidne smole, b) $200 \mathrm{~nm}$ silicij-epoksidne smole, c) $600 \mathrm{~nm}$ silicij-epoksidne smole in d) $(30+600) \mathrm{nm}$ silicij-epoksidne smole

the solid surface-tension $\gamma_{\mathrm{s}}$ values were determined using the least-squares analysis technique. For the fitting with Equation (2), a literature value of $\beta=0.0001234$ $\left(\mathrm{mJ} / \mathrm{m}^{2}\right)^{-2}$ was used, as weighted for a variety of solid surfaces $^{22}$. Again, the calculated values of the solid surface energy (Table 1) dropped significantly when the clean AISI 316L substrate was covered with silica/epoxy coatings, confirming the induced surface hydrophobicity. The low surface energy of the silica/epoxy coatings is most probably a consequence of the combination of silica-induced surface roughness and the appropriate surface chemistry due to the coatings' functionalization with fluoroalkylsilane.

\subsection{Surface morphology}

Figure 2 compares the typical morphology of various silica-epoxy coatings. It is clear that in spite of the silica-surface modification with an epoxy-compatible component, we could not prevent silica agglomeration in the coating. After several different attempts we came to the conclusion that the agglomeration appears during the curing process and is most probably a consequence of solvent (acetone) evaporation, together with the formation of a highly cross-linked epoxy structure.

A detailed look at the surface morphology, however, brought us to the conclusion that there exists a typical average agglomerate size, which depends on the size of the silica fillers in the epoxy matrix. These agglomerates, which are typically in the $\mu \mathrm{m}$ size range, consequently

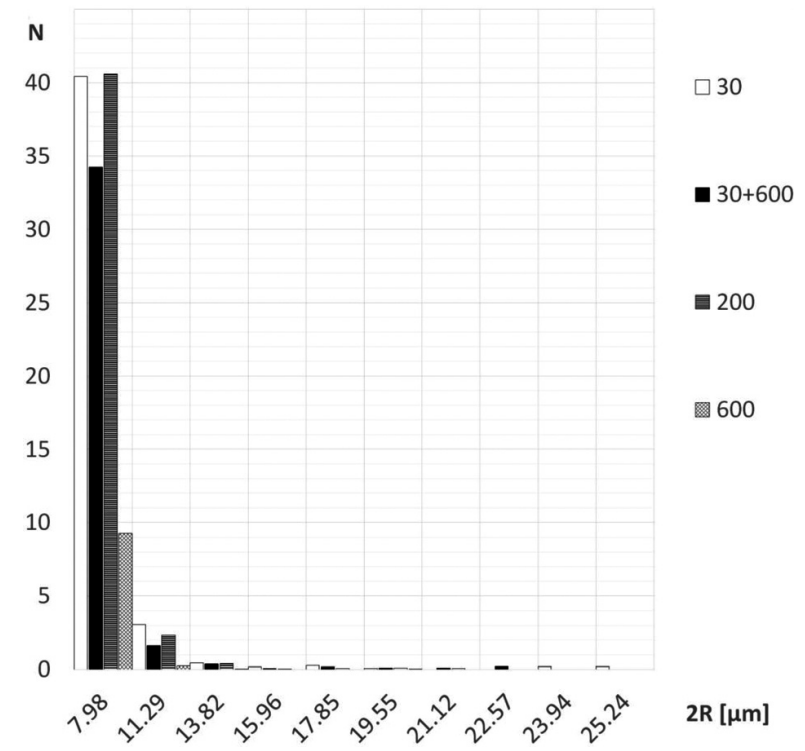

Figure 3: Size distribution of silica agglomerates in $30 \mathrm{~nm}, 200 \mathrm{~nm}$, $600 \mathrm{~nm}$ and $(30+600) \mathrm{nm}$ silica/epoxy coatings

Slika 3: Velikostna porazdelitev silicijevih aglomeratov v prevlekah iz epoksidne smole, obogatene s silicijevimi nanodelci $30 \mathrm{~nm}, 200 \mathrm{~nm}$, $600 \mathrm{~nm}$ in $(30+600) \mathrm{nm}$ 
create a micro-roughness on top of the nano-roughness created by the individual silica nanoparticles embedded in the epoxy matrix. As is already known, it is the combination of the two, i.e., the micro- and the nano-roughness, that increases the static water contact angle and makes the surface more hydrophobic ${ }^{25}$.

As reported in Table 1, we measured the highest static water contact angles, close to $120^{\circ}$, only on the surfaces of the $200 \mathrm{~nm}$ and $(30+600) \mathrm{nm}$ silica/epoxy coatings. In Figure 3 we can see that these two coatings are characterized mostly with agglomerates having diameters of $8 \mu \mathrm{m}$ and $11 \mu \mathrm{m}$. The same holds for the morphology of the $30 \mathrm{~nm}$ silica/epoxy coating; however, here we also observe an inconsiderable number of larger agglomerates that most probably influence the proper ratio between the micro- and nano-roughness necessary for an increase of the static water contact angle. This suggests the agglomerate/nanoparticle ratio is extremely sensitive to the appropriate surface roughness that will create a hydrophobic/superhydrophobic surface. This result also confirms the competitive importance of the surface morphology on the wetting properties compared to a low surface energy tailored with the surface chemistry.

\subsection{Surface Roughness}

Finally, we confirmed the morphology observations and determined the effect of the incorporation of silica on the morphology of the epoxy coating, by measuring the average surface roughness of the coatings, $S_{\mathrm{a}}$. An examination of the silica/epoxy-coated steel surface with a profilometer revealed that the nanoparticles' size significantly influences the coating's roughness and consequently the morphology of the surface. As listed in Table 2, $S_{\mathrm{a}}$ of $200 \mathrm{~nm}$ and $(30+600) \mathrm{nm}$ silica/epoxy coatings is of the same order of magnitude and in the intermediate regime compared to $30 \mathrm{~nm}$ and $600 \mathrm{~nm}$ silica/epoxy coatings. This is consistent with the observation of the average size of the agglomerates characterizing the morphology of each coating, as reported in the previous section. Here, we have shown that an intermediate roughness gives the best results in terms of an increased hydrophobicity (Tables $\mathbf{1}$ and 2). Moreover, this confirms the importance of the appropriate surface roughness on the wetting behaviour of the coatings.

Table 2: Average surface roughness, $S_{\mathrm{a}}$, of various silica/epoxy coatings on an AISI 316L substrate

Tabela 2: Povprečna površinska hrapavost $S_{\text {a }}$ različnih prevlek iz silicij-epoksidne smole na podlagi AISI $316 \mathrm{~L}$

\begin{tabular}{|c|c|}
\hline Substrate & $S_{\mathrm{a}}$ \\
\hline AISI $+30 \mathrm{~nm}$ silica/epoxy & 0.65 \\
\hline AISI $+200 \mathrm{~nm}$ silica/epoxy & 0.41 \\
\hline AISI $+600 \mathrm{~nm}$ silica/epoxy & 0.27 \\
\hline AISI $+(30+600) \mathrm{nm}$ silica/epoxy & 0.46 \\
\hline
\end{tabular}

\section{CONCLUSIONS}

Nanosilica particles were homogeneously dispersed in an epoxy matrix at a mass concentration of $2 \%$ and mixtures with different combinations of $30 \mathrm{~nm}, 200 \mathrm{~nm}$ and $600 \mathrm{~nm}$ silica were successfully spin coated on austenitic stainless steel of type AISI 316L to form a 300 $\mathrm{nm}$ coating. For an additional improvement of the non-wetting properties, the coatings were functionalized by dip-coating in ethanolic fluoroalkylsilane (FAS17).

The mechanical properties of the coatings were evaluated with a scratch test, indicating that the more brittle pure epoxy coating underwent more severe damage, accompanied by a pronounced material displacement compared to the silica/epoxy coating. This indicates that the silica particles enhanced the toughness of the epoxy coating.

The silica nanoparticles changed the microstructure of the epoxy coating, which was reflected in an increased roughness of the silica/epoxy-coated AISI 316L sample. The increased hydrophobicity of the silica/epoxy coatings, on the other hand, was a consequence of the combination of silica-induced surface roughness and the appropriate surface chemistry, due to the coatings' functionalization with fluoroalkylsilane.

The surface morphology of the silica/epoxy coatings was characterized by the formation of micrometre-size silica agglomerates as a consequence of the epoxy-matrix curing process. The significantly increased hydrophobicity in the $200 \mathrm{~nm}$ and $(30+600) \mathrm{nm}$ silica/epoxy coatings was connected to the proper combination of micro- and nano-roughness created by the agglomerates embedded in the epoxy matrix.

\section{Acknowledgement}

This work was carried out within the framework of the Slovenian programme P2-0132, "Fizika in kemija površin kovinskih materialov" of the Slovenian Research Agency, whose support is gratefully acknowledged by M. Conradi.

\section{REFERENCES}

${ }^{1}$ F. Galliano, D. Landolt, Evaluation of corrosion protection properties of additives for waterborne epoxy coatings on steel, Prog. Org. Coat., 44 (2002), 217-225, doi:10.1016/S0300-9440(02)00016-4

${ }^{2}$ S. Yamini, R. J. Young, Stability of crack-propagation in epoxy-resins, Polymer, 18 (1977) 10, 1075-1080, doi:10.1016/0032-3861(77) 90016-7

${ }^{3}$ B. Wetzel, F. Haupert, M. Q. Zhang, Epoxy nanocomposites with high mechanical and tribological performance, Comp. Sci. Tech., 63 (2003), 2055-2067, doi:10.1016/S0266-3538(03)00115-5

${ }^{4}$ A. C. Moloney, H. H. Kausch, T. Kaiser, H. R. Beer, Parameters determining the strength and toughness of particulate filled epoxideresins, J. Mat. Sci., 22 (1987), 381-393, doi:10.1007/BF01160743

${ }^{5}$ E. P. Giannelis, Polymer-layered silicate nanocomposites: Synthesis, properties and applications, App. Org. Chem., 12 (1998), 675-680, doi:10.1002/(SICI)1099-0739(199810/11)12:10/11<675::AID-AOC7 79>3.0.CO;2-V 
${ }^{6}$ T. Lan, T. J. Pinnavaia, Clay-reinforced epoxy nanocomposites, Chem. Mat., 6 (1994), 2216-2219, doi:10.1021/cm00048a006

${ }^{7}$ R. P. Singh, M. Zhang, D. Chan, Toughening of a brittle thermosetting polymer: Effects of reinforcement particle size and volume fraction, J. Mat. Sci., 37 (2002), 781-788, doi:10.1023/ A: 1013844015493

${ }^{8}$ R. A. Pearson, A. F. Yee, Influence of particle-size and particle-size distribution on toughnening mechanisms in rubber-modified epoxies, J. Mat. Sci., 26 (1991), 3828-3844, doi:10.1007/BF01184979

${ }^{9}$ M. Frounchi, T. A. Westgate, R. P. Chaplin, R. P. Burford, Fracture of polymer networks based on diethylene glycol bis(allyl carbonate), Polymer, 35 (1994), 5041-5045, doi:10.1016/0032-3861(94)90661-0

${ }^{10}$ R. T. Quazi, S. N. Bhattacharya, E. Kosior, The effect of dispersed paint particles on the mechanical properties of rubber toughened polypropylene composites, J. Mat. Sci., 34 (1999), 607-614, doi:10.1023/A:1004515300637

${ }^{11}$ T. Adachi, W. Araki, T. Nakahara, A. Yamaji, M. Gamou, Fracture toughness of silica particulate-filled epoxy composite, J. App. Polym. Sci., 86 (2002), 2261-2265, doi:10.1002/app.11206

${ }^{12}$ A. Boonyapookana, K. Nagata, Y. Mutoh, Fatigue crack growth behavior of silica particulate reinforced epoxy resin composite, Comp. Sci. Tech., 71 (2011), 1124-1131, doi:10.1016/j.compscitech. 2011.02.015

${ }^{13}$ J. Yuan, S. Zhou, G. Gu, L. Wu, Effect of particle size of nanosilica on the performance of epoxy/silica composite coatings, J. Mat. Sci., 40 (2005), 3927-3932, doi:10.1007/s10853-005-0714-8

${ }^{14}$ M. Conradi, M. Zorko, A. Kocijan, I. Verpoest, Mechanical properties of epoxy composites reinforced with a low volume fraction of nanosilica fillers, Mat. Chem. Phys., 137 (2013), 910-915, doi:10.1016/j.matchemphys.2012.11.001

${ }^{15}$ A. Tuteja, W. Choi, M. Ma, J. M. Marby, S. A. Mazzella, G. C. Rutledge, G. G. McKinley, R. E. Cohen, Designing superoleophobic surfaces, Science, 318 (2007), 1618-1622, doi:10.1126/science. 1148326
${ }^{16}$ C. H. Xue, S. T. Jia, J. Zhang, L. Q. Tian, H. Z. Chen, M. Wang, Preparation of superhydrophobic surfaces on cotton textiles, Sci. Technol. Adv. Mater., 9 (2008) 3, 035008, doi:10.1088/1468-6996/ 9/3/035008

${ }^{17}$ A. Zenerino, T. Darmanin, E. T. deGivenchy, S. Amigoni, F. Guittard, Connector ability to design superhydrophobic and oleophobic surfaces from conducting polymers, Langmuir, 26 (2010), 13545-13549, doi:10.1021/la101734s

${ }^{18}$ N. Salema, D. K. Sarkar, R. W. Paynter, X. G. Cheng, Superhydrophobic aluminum alloy surfaces by a novel one-step process, ACS Appl. Mater. Interfaces, 2 (2010), 2500-2502, doi:10.1021/ la104979x

${ }^{19}$ Z. Guo, X. Chen, J. Li, J. H. Liu, X. J. Huang, ZnO/CuO heterohierarchical nanotrees array, hydrothermal preparation and selfcleaning properties, Langmuir, 27 (2011), 6193-6200, doi:10.1021/ la104979x

${ }^{20}$ W. Stober, A. Fink, E. Bohn, Controlled growth of monodisperse silica spheres in micron size range, Journal of Colloid and Interface Science, 26 (1968), 62-69, doi:10.1016/0021-9797(68)90272-5

${ }^{21}$ D. Li, A. W. Neumann, A reformulation of the equation of state for interfacial-tensions, Journal of Colloid and Interface Science, 137 (1990), 304-307, doi:10.1016/0021-9797(90)90067-X

${ }^{22}$ D. Y. Kwok, A. W. Neumann, Contact angle measurement and contact angle interpretation, Advances in Colloid and Interface Science, 81 (1999), 167-249, doi:10.1016/S0001-8686(98)00087-6

${ }^{23}$ J. Y. Shiu, C. W. Kuo, P. L. Chen, C. Y. Mou, Fabrication of tunable superhydrophobic surfaces by nanosphere lithography, Chem. Mat., 16 (2004), 561-564, doi:10.1021/cm034696h

${ }^{24}$ Y. Y. Yu, C. Y. Chen, W. C. Chen, Synthesis and characterization of organic - inorganic hybrid thin films from poly(acrylic) and monodispersed colloidal silica, Polymer, 44 (2003), 593-601, doi:10.1016/ S0032-3861(02)00824-8

${ }^{25}$ T. J. Athauda, W. Williams, K. P. Roberts, R. R. Ozer, On the surface roughness and hydrophobicity of dual-size double-layer silica nanoparticles, J. Mater. Sci., 48 (2013) 18, 6115-6120, doi:10.1007/ s10853-013-7407-5 